learning. Considerable attention was paid to the disclosure of the following methods of teaching a foreign language: interactive lectures, discussions, case studies, project method, interviews, "aquarium", debates, role and business games, internal/external circles and others. The classification of these methods is given: methods of individualized teaching and learning (interaction of one cadet with one teacher or one subject of study with another subject); teaching methods through the interaction of subjects of study (self-study) with educational resources; methods that are characterized by active interaction between all participants in the educational process, etc.

The article substantiates that introduction of computer technologies is also perspective at the present stage, which will increase the efficiency of foreign language training of future officers. Under the conditions of the COVID-19 spread, modern information and telecommunications technologies have become extremely relevant, namely: online platforms and databases (MOODLE, Wiki, and other), computer programs and mobile applications, various multimedia Internet resources. The most used resources in the period of forced transition of higher military education institutions of Ukraine to online training were such platforms and programs as Zoom, Skype, Google Classroom (Forms), Google Meet, BigBlueButton - software product for video conferencing with native speakers, etc.

Key words future officers, teaching methods, foreign language, higher military education institutions.

удк 378.015 .3

Ірина Самохвалова

Сумський державного педагогічний університет імені A. С. Макаренка ORCID ID 0000-0001-7017-6915

Петро Рибалко

Сумський державний педагогічний університет імені А. С. Макаренка ORCID ID 0000-0002-6460-4255

Олександр Моргунов

Харківський національний університет внутрішніх справ

ORCID ID 0000-0003-2259-3620

DOI 10.24139/2312-5993/2020.10/235-244

\title{
РУХОВА АКТИВНІСТЬ ТА МОТИВАЦІЯ ДО ЗАНЯТЬ ІЗ ФІЗИЧНОГО ВИХОВАННЯ СТУДЕНТОК ЗАКЛАДІВ ВИЩОЇ ОСВІТИ
}

Потреба в русі - біологічна потреба організму людини, що відіграє важливу роль у ії життєдіяльності та знаходиться в нерозривному зв'язку з активною м'язовою діяльністю, що сприяє адаптації до навколишнього середовища. у даному дослідженні велика увага присвячена мотиваційним пріоритетам щодо занять фрізичними вправами протягом робочого дня, як одного з чинників поліпшення показників рухової активності студенток. Визначення оптимального підходу до організачії рухової активності, добових енерговитрат та мотиваційних потреб у руховій активності здобувачів вищої освіти, який дозволить підвищити активність і зацікавленість у досягненні високого рівня власного фрізичного здоров'я студенток зВО.

Ключові слова: рухова активність, рівні рухової активності, мотивація, фозичне виховання, студентки. 
Постановка проблеми. На сучасному етапі постійно підвищуються вимоги суспільства до якості підготовки та конкурентоспроможності майбутнього фахівця. Адаптація молодих спеціалістів до нових умов роботи вимагає від них професійної компетентності, мобільності, стійкої працездатності, доброго здоров'я, що у своїй єдності сприяють високій продуктивності праці.

Заклад вищої освіти повинен організувати для здобувачів таку форму фізичної активності, яка ґрунтувалася 6 на науковій основі, усвідомленні й особистісному ставленні студентів до збереження власного здоров'я, формувала систему цінностей і відповідної поведінки в напрямі здоров'язбережувальної діяльності.

Достатній рівень рухової активності студенток $є$ основою належного розвитку й формування організму (Лазоренко, 2013).

Аналіз літературних даних свідчить про те, що за останні роки обсяг навчального навантаження студентів у закладах вищої освіти зріс. Це зумовило викликані цим малорухомість, обмеження м'язових зусиль і спричиняє захворювання різних систем організму (Гакман, Балацька, Григоришина, Ніколайчук, 2018; Рибалко, Самохвалова, 2020).

Виникає проблема визначення оптимального підходу до організації рухової активності здобувачів вищої освіти, який дозволить підвищити активність і зацікавленість у досягненні високого рівня власного фізичного здоров'я.

Аналіз актуальних досліджень. Рухова активність - це частина поведінки людини, яка забезпечує нормальне функціонування систем організму та збереження здоров'я (Рибалко, Самохвалова, 2020; Ядвіга, Коробейников, Петров, Коваль, Дудник, 2009).

Механізм взаємозв'язку рухової активності й функціональних спроможностей організму розкриваються в дослідженнях багатьох авторів При цьому Ю. П. Ядвіга, Г. В. Коробейников, Г. С. Петров зазначають, що чим інтенсивніша рухова активність у межах допустимого оптимуму, тим більше виражені основні фактори, що збільшують енергетичні ресурси, функціональні спроможності, продуктивність інтелектуальної діяльності та тривалість життя (Ядвіга, Коробейников, Петров, Коваль, Дудник, 2009).

О. С. Калашник зауважує, що рухова активність визначається вираженою мотиваційною спрямованістю; високим рівнем вимог до досконалості рухових навичок під час виконання діяльності; високим рівнем вимог до особистісних якостей і психічних станів, адекватним умовам, у яких діє індивід (Калашник, 2011). 
На думку В. Д. Винника, вивчення мотивів, які активізують прагнення студента до систематичних занять фізичними вправами, є однією з важливих педагогічних проблем у фізичному вихованні, оскільки мотиви мають вирішальне значення в поведінці та стимуляції активної діяльності (Винник, 2010).

Формування повноцінної мотивації до занять А.В.Гакман, Л. В.Балацька, Т. Б. Григоришина, О.П. Ніколайчук вважають одним 3 шляхів збільшення ефективності системи фізкультурної освіти, фізкультурно-оздоровчої діяльності студентів (Гакман, Балацька, Григоришина, Ніколайчук, 2018; Рибалко, Самохвалова, 2020).

Мета дослідження: визначити добові енерговитрати, рівень рухової активності та мотиваційні потреби в руховій активності студенток.

\section{Завдання дослідження:}

1. Визначити рівень рухової активності студенток ЗВО.

2. Провести порівняльний аналіз показників рухової активності студенток.

3. Проаналізувати мотиваційні потреби в руховій активності студенток для оптимальної організації системи фізичного виховання.

Для вирішення визначених дослідницьких завдань застосовувався комплекс таких методів: аналіз науково-методичної літератури з проблеми дослідження, педагогічне спостереження, анкетування, методи математичної статистики.

Результати досліджень та їх обговорення. Дослідження проводилися в Сумському національному аграрному університеті (СНАУ) та Сумському державному педагогічному університеті імені А. С. Макаренка (СумДПУ). Було опитано й обстежено 150 студенток. Оцінка рухової активності проводилася за методикою Фремінгемського дослідження (Круцевич, Воробьєв, Безверхня, 202-203) з визначенням індексу фізичної активності й використанням хронометражу добової рухової активності.

Фремінгемська методика дозволяє кількісно та якісно визначати добову рухову активність на основі хронометражу добової діяльності різного характеру з реєстрацією інтенсивності кожного виду фізичних зусиль.

Величина цих вимірів подається у вигляді цифрового значення індексу фізичної активності у хронометражі, де реєструється вся діяльність, що займає за часом більше 5 хв. При цьому не повинно бути проміжків в описі. Описується день цілком від моменту, коли студентка прокинулася після нічного сну до того часу, коли вона лягла спати. Уся рухова активність людини розподіляється на п'ять рівнів; базовий, сидячий, малий, середній і високий. Кожному рівню відповідають певні види фізичної активності. 
Кожен рівень має енергетичну вартість залежно від витрачених ккал/хв-1 (відповідно: 1,25; 1,4; 2,05; 3,0; 6,25), що дозволяє розрахувати енергетичні добові витрати кожної студентки та скласти середньостатистичну модель режиму рухової активності, властиву певному контингенту університету.

Дані показників рухової активності студенток педагогічного та аграрного університетів за добу наведені в таблиці 1.

Таблиця 1

Показники рухової активності студенток

\begin{tabular}{|c|c|c|c|c|}
\hline \multirow[t]{2}{*}{ Рівні активності } & \multicolumn{2}{|l|}{ CHAY } & \multicolumn{2}{|c|}{ Сум ДПУ } \\
\hline & години & бали $\dot{X} \pm 0$ & години & Бали $\dot{X} \pm 0$ \\
\hline Малий рівень & 7,64 & $7,60 \pm 0,78$ & 7,82 & $7,85 \pm 0,52$ \\
\hline Сидячий рівень & 6,78 & $7,45 \pm 0,54$ & 6,85 & $7,53 \pm 0,41$ \\
\hline Середній рівень & 8,79 & $13,18 \pm 1,32$ & 8,79 & $13,09 \pm 1,23$ \\
\hline Базовий рівень & 0,50 & $1,20 \pm 0,94$ & 0,41 & $0,98 \pm 0,48$ \\
\hline Високий рівень & 0,29 & $1,45 \pm 0,73$ & 0,28 & $1,40 \pm 0,56$ \\
\hline
\end{tabular}

На малому рівні, до якого відносяться особиста гігієна, пересування пішки, академічні заняття, окрім фізичної культури, у студенток Сумського державного педагогічного університету імені А. С. Макаренка рівень рухової активності становить 8,73 години. У студенток Сумського національного аграрного університету цей показник становить 8,79 години.

Перегляд телепередач, читання, підготовка до занять в інституті, їзда сидячи, комп'ютерні ігри, прийом їжі - види діяльності, які належать до сидячого рівня рухової активності, на нього в середньому студентки СНАУ витрачають 6,78 години, а дівчата зі СумдПУ - 6,85 години.

На середньому рівні (домашня робота по господарству, прогулянки, ранкова гімнастика) показник рухової активності для студенток СНАУ склав 0,38, тоді як для студенток СумДПу - 0,41 години.

Середній показник на базовому рівні (сон, відпочинок лежачи) для контингенту дівчат, які взяли участь у дослідженні, становить у студенток СНАУ - 7,64 години, у дівчат Сумського державного педагогічного університету - 7,82 години. Заняття фізичними вправами, різноманітними рухливими та спортивними іграми, спортом складають високий рівень рухової активності. На нього близько 0,39 години витрачають представниці СНАУ та 0,28 години - майбутні педагоги студентки СумДПУ.

За результатами дослідження встановлено, що показники добової рухової активності студенток Сумського національного аграрного університету та Сумського державного педагогічного університету $\epsilon$ нижчими за норму. Так, на заняття фізичною культурою і спортом протягом доби студентки виділяють 0,285 години; на перегляд телепередач, 
читання, підготовка до занять в інституті, їзда сидячи, комп'ютерні ігри, прийом їжі студентки витрачають у середньому 6,81години.

За обмеженої рухової активності знижуються захисні механізми організму до факторів, що шкодять здоров'ю людини, створюється схильність до захворювань. Беручи до уваги фізичний стан студентів, які досліджуються, середній і нижчий за середній рівні фізичної підготовленості, а також середній рівень фізичного розвитку, можна зробити висновок, що студентки Сумських університетів мають недостатній рівень рухової активності, що не сприяє підтриманню високого функціонального стану організму

Аналіз наукових джерел та узагальнення результатів розвідок С. А. Лазоренко (Лазоренко, 2013) дає нам можливість порівняли показники рухової активності студенток Сумських університетів в 2013 та 2020 роках (рис 1.).

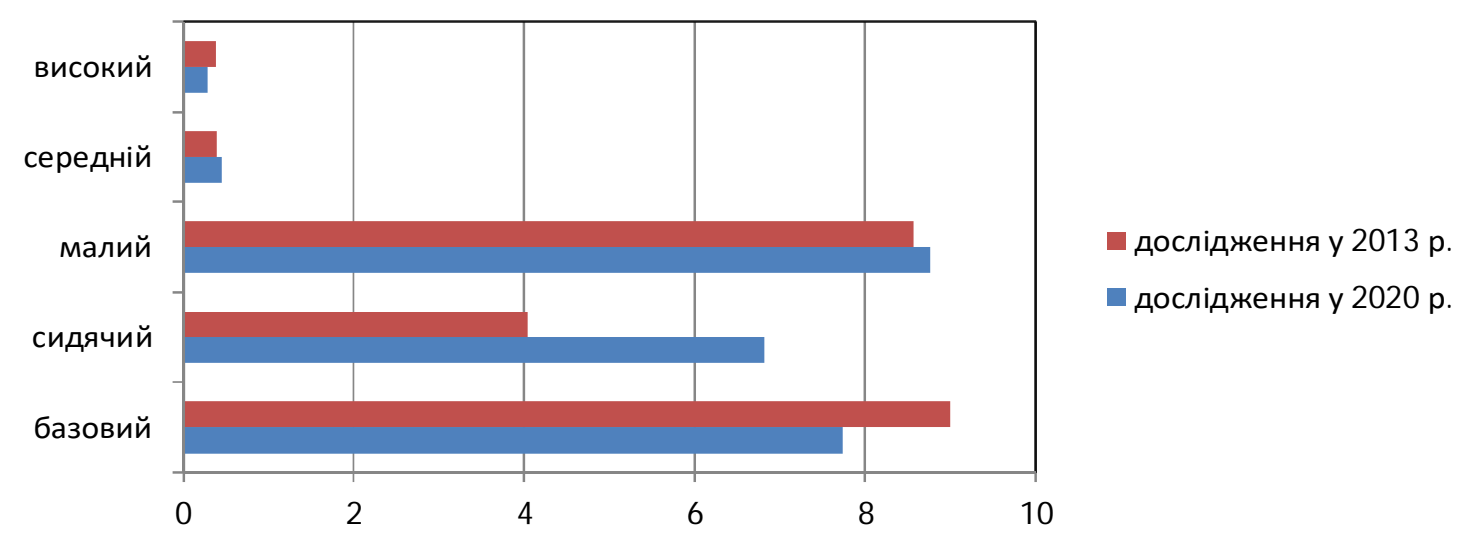

Рис. 1. Результати показників рухової активності студенток (год.)

У результаті аналізу отриманих даних відзначається зниження рухової активності базового $16,42 \%$ та високого $36,84 \%$ рівнів фізичної активності студентів. На сидячому рівні спостерігається приріст показників рухової активності на 40,71\%. Це пов'язано зі зміною структури спеціальних дисциплін, що викладають у закладах вищої освіти, i, внаслідок цього, збільшенням часу на підготовку до занять і самостійну роботу студента. Відповідно до вимог кредитно-модульної системи аудиторні заняття повинні складати не більше ніж 60 \% загальної кількості годин. Отже, у студентів збільшується кількість годин на самостійну роботу, яку вони найчастіше виконують сидячи за комп'ютером або в бібліотеці.

Фізична культура і спорт можуть протидіяти негативним наслідкам обмеження рухового режиму студентів, бути важливим засобом збереження та зміцнення здоров'я, всебічного розвитку, покращення 
працездатності та зниження втомлюваності, підвищення опірності організму до різних захворювань у період навчання (Гакман, Балацька, Григоришина, Ніколайчук, 2018).

Рівень мотивації до занять із фізичного виховання, на нашу думку, може бути одним із чинників, який впливає на показники рухової активності студенток. Тому ми провели анкетування, метою якого $€$ визначення ставлення студенток університету до занять фізичною культурою і спортом та цінностями здоров'я. Респондентами виступали студентки Сумського національного аграрного університету та Сумського державного педагогічного університету імені А. С. Макаренка в кількості 148 чоловік.

Отримані дані свідчать про те, що основним позитивним мотивом, щоб займатися фізичною культурою і спортом для більшості студенток $\epsilon$ зміцнення здоров'я (44,9%). Потім ідуть мотиви - удосконалення фізичної форми (35,1\%); отримання заліку та високого балу рейтингу (29,1\%). Менш цінними мотивами до занять фізичною культурою і спортом були емоційна розрядка (2,15 \%) та організація дозвілля (3,22 \%).

Це свідчить про те, що студентки не до кінця усвідомлюють користь занять фізичними вправами.

Підтвердження цьому ми бачимо, аналізуючи результати анкети. На питання про чинники, які сприяють збереженню й поліпшенню здоров'я. Найбільш ефективною формою 49,5\% студенток називають сон і відпочинок, 29,9\% - помірні фізичні навантаження та здоровий спосіб життя, 8,8 \% - вживання ліків та вітамінів, 4,4\% - не бачать необхідності приймати будь - які заходи.

За допомогою опитування ми з'ясували, що $61,5 \%$ студенток вважають стан свого здоров'я задовільний, 18,7\% - не можуть похвастатися гарним здоров'ям, 13,2\% респондентів вважають себе абсолютно здоровими.

Суб'єктивна оцінка здоров'я не відповідає об'єктивним показникам. об'єктивні дослідження показали, що 35,8 \% студенток мають низький рівень здоров'я, 32,7 \% - нижче за середній, 28,5 \% - середній рівень.

При цьому, коли особисте здоров'я оцінюється високо, головний мотив заняття фізичною культурою і спортом - покращення здоров'я втрачає своє значення.

Коли йдеться про спеціально організовану рухову активність необхідно з'ясувати зміст та особисту значимість цієї діяльності.

В одному з питань анкети пропонувалось обрати найбільш привабливий, для студенток вид заняття. Для вирішення цього завдання 
студенткам у відповідях на запитання анкети, було запропоновано назвати вид діяльності, який, на їх думку, може замінити традиційний зміст занять з фізичного виховання ( рис 2.).

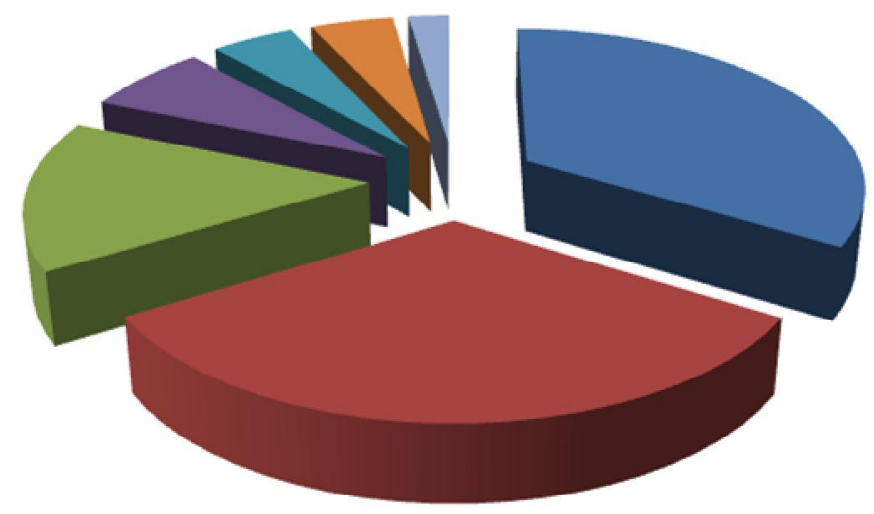

$$
\begin{aligned}
& \text { волейбол } \\
& \text { фітнес } \\
& \text { бадминтон } \\
& \text { вільна боротьба } \\
& \text { тхеквандо } \\
& \text { міні -футбол } \\
& \text { настільний теніс }
\end{aligned}
$$

Рис. 2. Вибір видів рухової активності за результатами анкетування (\%)

Аналізуючи відповіді ми з'ясували, що найбільш популярними видами спорту для студенток є волейбол 33,9\% та фітнес 33,7 \%, дещо менший відсоток бажають займатися бадмінтоном 15, \%, вільною боротьбою $7 \%$.

Зазначене доводить, що в сучасних умовах інтерес до занять фізичною культурою могли б підвищити заняття тими видами, до яких $\epsilon$ схильність, тобто студентка має сама обрати ті види рухової активності, які їй до вподоби.

У процесі вибору форм проведення занять 45,6 \% обрали групові заняття обраним видом спорту, 23,3 \% - самостійні індивідуальні заняття та $15,3 \%$ - самостійні заняття з товаришем.

При цьому виявлено, що 45,1 \% студенток вважають що недостатньо часу приділяють заняттям фізичною культурою і спортом, 40,7 \% - вважають достатнім часу, який вони приділяють заняттям фізичними вправами.

У результаті обробки анкет ми визначили чинники, що сприяють фізкультурній пасивності студенток: відсутність душу після занять - 37,36 \%; відсутність часу - 35,16 \%; носіння спортивної форми - 20,88\%; невідповідність навчальних навантажень рівню фізичної підготовленості $14,29 \%$, а 8,79 \% респондентів не бачать необхідності в заняттях.

Одним із немаловажних чинників формування мотиву, є умови, у яких проводять заняття з фізичного виховання.

\section{Висновки.}

1. За даними дослідження рівня рухової активності студенток установлено, що показники добової рухової активності студенток Сумських 
вишів є нижчими за норму. Показники добової рухової активності дівчат, які навчаються в Сумському національному аграрному університеті та Сумському державному педагогічному університеті на малому, середньому, сидячому та базовому рівнях статистично вірогідно не відрізняються. Різниця коливається в межах 0,39 \% протягом доби.

Кількість часу, який витрачають дівчата СНАУ на базовому рівні, на 1,9 \% протягом доби більша за дівчат із СумДПУ.

2. Аналізуючи показники рухової активності студенток Сумських вишів у 2013 та 2020 роках, ми бачимо, що відбулася зміна показників на базовому, високому та сидячому рівнях рухової активності. Це говорить про те, що студентки витрачають на 40,7 \% більше часу на перегляд телепередач, читання, підготовка до занять в інституті (сидячий рівень), і на 36,84 \% менше часу на заняття фізичними вправами (високий рівень).

3. Проведене соціологічне дослідження та аналіз отриманих результатів показав, що у студенток пріоритетним мотивом для занять фізичною культурою і спортом $є$ мотив зміцнення здоров'я. Рівень матеріально - технічного забезпечення відіграє важливу роль у мотивації студенток до занять фізичними вправами. Результати проведеного анкетування виявили незадоволеність студенток традиційним змістом занять із фізичного виховання, що підтверджує необхідність застосування нових підходів до організації системи фізичного виховання студентської молоді.

\section{ЛІТЕРАТУРА}

Винник, В. Д. (2010). Особливості формування інтересу та мотивації до занять фізичним вихованням. Теорія та методика фрізичного виховання, 12, 39-42 (Vinnik, V. D. (2010). Features of interest formation and motivation for physical education. Theory and methods of physical education, 12, 39-42).

Гакман, А. В., Балацька, Л. В., Григоришина, Т. Б., Ніколайчук, О. П. (2018). Мотиваційні пріоритети до процесу фізичного виховання студентів закладів вищої освіти I рівня акредитації (на прикладі м. Чернівці). Вісник Кам'янець-Подільського національного університету імені Івана Огієнка. Фізичне виховання, спорт $і$ здоров'я людини, 11, 53-61 (Hakman, A. V., Balatska, L. V., Grigorishina, T. B., Nikolaychuk, O. P. (2018). Motivational priorities for the process of physical education of students of higher education institutions of the I level of accreditation (on the example of Chernivtsi). Bulletin of Kamyanets-Podilsky National University named after Ivan Ogienko. Physical Education, Sport, and Human Health, 11, 53-61).

Гринчук, А., Чехівська, Ю. (2018). Застосування інноваційних технологій як засобу підвищення мотивації студентів до занять фізичним вихованням. Науковий вісник Мелітопольського державного педагогічного університету. Серія: Педагогіка, 1, 145-150 (Hrynchuk, A., Chekhivska, Yu. (2018). The use of innovative technologies as a means of increasing students' motivation to engage in physical education. Scientific Bulletin of Melitopol State Pedagogical University. Series: Pedagogy, 1, 145-150). 
Калашник, О. С. (2011). Стимулювання активності студентів до спортивної діяльності. Актуальні проблеми теорії і методики фрізичного виховання, 69-75 (Kalashnik, O. S. (2011). Stimulating students' activity in sports. Actual problems of the theory and methods of physical education, 69-75).

Круцевич, Т. Ю., Воробьев, М. І., Безверхня, Г. В. Контроль у фізичному вихованні дітей, підлітків і молоді. Режим доступу: dspace.udpu.edu.ua (Krutsevich, T. Yu., Vorobiev, M. I., Bezverkhnya, G. V. Control in physical education of children, teenagers and youth. Retrieved from: dspace.udpu.edu.ua).

Лазоренко, С. А. (2013). Рівень рухової активності учнівської молоді вищих навчальних закладів Сумщини. Слобожанський науково-спортивний вісник, 4 (27), 34-37 (Lazorenko, S. A. (2013). The level of motor activity of students of higher educational institutions of Sumy region. Slobozhansky Scientific and Sports Bulletin, 4 (27), 34-37).

Рибалко, П. Ф., Самохвалова, І. Ю. (2020). Аналіз розвитку рухових здібностей студенток закладів вищої освіти засобами спортивних ігор у процесі секційних занять. Modern researcher in psychology and pedagogy: collective monograph. Riga: Izdevnieciba "Baltija Publishing", pp. 333-352 (Rybalko, P. F., Samokhvalova, I. Yu. (2020). Analysis of the development of motor abilities of students of higher education institutions by means of sports games in the process of sectional classes. Modern researcher in psychology and pedagogy: collective monograph. Riga: Izdevnieciba "Baltija Publishing", pp. 333-352).

Ядвіга, Ю. П., Коробейніков, Г. В., Петров, Г. С., Коваль, С. Б., Дудник, О. К. (2009). Вплив рухової активності на психоемоційний стан студентів вузу економічних спеціальностей в сучасних умовах навчання. Педагогіка, психологія та медикобіологічні проблеми фрізичного виховання і спорту, 12, 202-204 (Yadviga, Yu. P., Korobeynikov, G. V., Petrov, G. S., Koval, S. B., Dudnik, O. K. (2009). The influence of motor activity on the psycho-emotional state of students of economic specialties in modern learning conditions. Pedagogy, Psychology and Medical and Biological Problems of Physical Education and Sports, 12, 202-204).

\section{PEЗЮME}

Самохвалова Ирина, Рыбалко Петр, Моргунов Александр. Двигательная активность и мотивация к занятиям по физическому воспитанию студенток высшего образования.

Потребность в движении - биологическая потребность организма человека, играет важную роль в его жизнедеятельности и находится в неразрывной связи с активной мышечной деятельностью, способствует адаптации к окружающей среде. В данном исследовании большое внимание посвящено мотивационным приоритетам проведения занятий физическими упражнениями в течение рабочего дня, как одного из факторов улучшения показателей двигательной активности студенток. Определение оптимального подхода к организации двигательной активности, суточных энергозатрат и мотивационных потребностей $в$ двигательной активности соискателей высшего образования, который позволит повысить активность и заинтересованность в достижении высокого уровня собственного физического здоровья студенток зВО.

Ключевые слова: двигательная активность, уровень двигательной активности, мотивация, физическое воспитание, студентки. 


\section{SUM MARY}

Samokhvalova Iryna, Rybalko Petro, Morhunov Oleksandr. Physical activity and motivation for physical education classes of female students of higher education institutions.

The need for movement is a biological need of the human body, which plays an important role in its vital activity and is inextricably linked with active muscular activity, which promotes adaptation to the environment.

The article is devoted to the study of motivational priorities for physical education as one of the factors of improving the indicators of motor activity of female students. The purpose of the study is to determine daily energy expenditure, level of physical activity and motivational needs in physical activity of female students.

To solve the outlined research problems, a set of methods was used: analysis of scientific and methodological literature on the problem of research, pedagogical observation, questionnaires, methods of mathematical statistics. Assessment of motor activity was performed according to the method of the Framingham study with determination of the index of physical activity and the use of timing of daily motor activity.

Students of Sumy State Pedagogical University named after A.S. Makarenko and Sumy National Agrarian University took part in the experiment. The obtained data helped to determine the amount of time spent by university students at different levels of physical activity, to compare the indices of physical activity of female students of some higher education institutions of Sumy region.

According to the study of the level of motor activity of female students, it has been found that the indicators of daily motor activity of female students of Sumy universities are lower than normal.

As a result of the analysis of the received data there was determined the decrease in motor activity of basic $(16,42 \%)$ and high $(36,84 \%)$ levels of students' physical activity. At the sedentary level, there is an increase in motor activity by $40,71 \%$. As a result, in female students increases the number of hours they read, prepare for classes, and work independently, which they often do while sitting at a computer or in the library.

The motivational priorities of university students to the process of physical education are determined. It has been found that a significant role in optimizing the motor activity of female students plays their motivation to engage in physical education classes and the use of physical culture in everyday life.

Key words: motor activity, levels of motor activity, motivation, physical education, female students. 